\title{
The Effect of Instructional Strategies and Social Interaction on Social Science Learning Outcome
}

\author{
Fitri Amelia Ritonga \\ Educational Technology, Postgraduate Program \\ Universitas Negeri Medan \\ Medan, Indonesia \\ fitriameliaaaa@gmail.com
}

\author{
Abdul Muin Sibuea \\ Educational Technology \\ Universitas Negeri Medan \\ Medan, Indonesia
}

\begin{abstract}
This study aims to: (1) know the learning outcome of students in social science who are taught with problem based learning strategy and two stay two stray strategy, (2) know the social science learning outcome of students with cooperative and competitive social interaction (3) know the interaction between the learning strategies and the social interaction in affecting the learning outcome in social science. This research is a quasiexperimental study which involved 84 Junior High School students grade VIII in two different schools. The data was analyzed with descriptive statistics to describe the state of the data. The analysis requirements with Liliefors and Bartlett tests are fulfilled. The hypothesis testing uses ANOVA 2 ways. From the data analysis, it can be concluded that the appropriate instructional strategy used for students with cooperative social interaction is the problem based learning strategy while for students with competitive social interaction is two stay two stray strategy. The implication of this study is specificially for social science teachers, in which to implement the learning strategies, they have to watch the characteristics of students, especially their social interaction.
\end{abstract}

Keywords: instructional strategies, social interaction, learning outcome

\section{INTRODUCTION}

Education is one thing that is very important to equip students for the future. For this reason, a meaningful learning process will determine the realization of quality education. Students need to have adequate guidance, encouragement, and opportunities to learn things that will be needed in their lives.

Education has functions to help students in their development, namely the development of all their potential, skills, and personal characteristics in a positive direction, both for themselves and their environment. As one of the mandate in the opening of the law 1945, national education seeks to educate the nation's life through learning and civilizing the nation and society of Indonesia so that every Indonesian human being is educated, cultured, intelligent, has a strong mind on morals and culture, and also social justice.

Waite \& Hume (2016) [1] explain that in generally the difficulties by students when learning are related to the inappropriate between the use of strategies and models with the types of individual student characteristics. The problem solving of learning can be overcome by giving greater freedom and autonomy and opportunities to optimize competency abilities in solving various problems. This can be done by utilizing a learning environment that includes resources, strategies, methods, and media in accordance with their potential abilities (Weiss, 2017) [2]

Sapriya (2009: 7) [3] explain that social sciences learning in Indonesia began to be known since the 1970, and formally began to be used in the national education system in the 1975 curriculum. In the curriculum documents, social sciences learning is one of the names of subjects given at the level of primary and secondary education. Social studies is a name of integration subjects from the subjects of History, Geography, Economics and other social science subjects.

Supardan (2015: 18) [4] explain that, there are four important things in social studies lessons, namely: (1) social studies objects for junior high school are social issues with elements of their study in the context of events, facts, concepts, and generalizations; (2) the themes studied in social studies are phenomena that occur in society both past, present and future trends; (3) social material consists of Geography, History, Sociology, and Economics; and (4) the aim of social studies learning is so that students become citizens of Indonesia who are democratic, responsibility, and citizens who like the world peace.

School is a place and center of learning. The national education system paradigm which has been a reference for conducting education in Indonesia needs to be reviewed and refined. The national education system paradigm must include process factors and context in addition to education inputs and outputs even in terms of educational input it is not really a problem. It is the process and context factors that will determine education output. Therefore, issues such as curriculum, teacher quality, effective and interest teaching methods and management are very important in the process of the system which becomes increasingly capable of developing their skills and personality.

In this connection, the teacher has an important role in advancing education, so the quality of education is largely determined by the quality of a teacher. In terms of human resource development, the role of the teacher is prioritized which will affect the quality of students. The phenomenon of 
many students who fail in learning is caused by many factors, one of the factors that influence is due to the low quality of education factors and is caused by the lack of ability of teachers to apply teaching to students. The level of learning is low, mainly because of the ability of teachers who are still applying monotonous old style teaching so that the teaching and learning process that occurs is not optimal to increase student motivation.

Based on the problems that have been explained above, it is necessary to have an effort made by a teacher to use teaching strategies that make the learning atmosphere more interesting so that it can increase the interest and motivation of students to follow the learning process.

Rachmah (2014: 153) [5] explain that social studies learning is essentially a transactional communication process that is reciprocal between teachers and students, and between students and others in learning social studies to achieve the objectives of social studies. The learning model that is in accordance with the social studies lesson is a learning model that is based on the constructivism paradigm approach, which is learning based on active participatory students in solving problems and thinking critically.

SMP PGRI-3 is located on Abdul Sani Muthalib street subdistrict Medan Marelan and SMP Al Hikmah is located on Marelan I street subdistrict Medan Marelan found that teachers in teaching social studies subjects use conventional strategies learning. The learning strategy used by the teacher has been less effective. The teacher only explains the lesson in front of the class while students sit and listen so that makes students feel bored in following the learning process. Based on the survey in two schools, the average value of social studies subject exams over the past three years is still quite unsatisfactory. This can be seen from the value of students who have not reached yet the standard mark.

Based on the reality of individual differences, not all students can achieve the expected goals. For students who are judged to have still not achieved their goals, the teacher is responsible for helping to achieve learning outcomes through improved learning processes. The success of a teacher is about the ability to carry out the teaching and learning process as well as possible so that students achieve the expected goals. By implementing an appropriate learning strategy, it is expected to help students improve their learning outcomes.

Social interaction is the relationship between one individual and another individual, one individual can influence other individuals, individuals with groups, and groups with individuals. There are three types of individual behavior in social interaction, such as: the same worker (cooperator) is a behavior that is concerned with maximizing the rewards received and received by friends, competitors (competitors) are behaviors that are oriented towards maximizing their own results so that more than their friend's results, and individualists are behaviors that prioritize maximizing their own results regardless of the defeat or victory of their friend.
To better know whether students have social interaction cooperatively can be seen from their characteristics, such as consensus, like the existence of mutual acceptance of rules or normative conditions concerning issues that are relevant to the group, mutual interest in the form of personal liking and each member considers the value of the benefits obtained between them, and solidarity is a coordinated response in a group where the behavior of members in the group simultaneously or sequentially mutually reinforcing groups that the principles. While competitive social interaction is individualist person without care with other person.

Problem based learning strategies are learning strategies that encourage students to know how to learn and work together in groups to find solutions to problems in the real world. Problem simulations are used to activate student curiosity before starting to study a subject. Problem-based learning strategies prepare students to think critically and analytically, and are able to get and use appropriate learning resources.

\section{RESEARCH METHOD}

This research was located at SMP PGRI-3 and SMP Al Hikmah Medan. This research will be carried out in the even semester of 2018/2019. The research treatments were carried out by adjusting the social science lesson schedule at the school. This research was from January to March 2019.

The population of this study was all students of Class VIII SMP PGRI- 3 consisting of 8 classes with the total number of students being 275 students and all students of Class VIII SMP Al Hikmah Medan consisting of 10 classes with 472 students. The selection of the school as the object of research is based on the assumption that schools with the same status are both private schools as well as teachers who study social studies are equally experienced teachers. Both schools use the 2013 curriculum and are in the same area but with different locations.

The sampling technique in this study is a random sample technique group (clutster random sampling) that is from 18 classes consisting of 8 classes of SMP PGRI 3 and 10 classes of SMP Al Hikmah Medan selected 2 classes as samples subject to treatment through selection.

This study illustrates the interactive influence between variables of learning strategies and social interactions on learning outcomes. This research uses an experimental method with a quasi experimental design with $2 \times 2$ factorial design. Through this design, it will be seen how the influence of problem based learning strategies and two stay two stray on student social learning outcomes and student social interaction. Problem based learning strategies and two stay two stray learning strategies are needed for student experimental groups with different levels of social interaction. Problem based learning strategies and two stay two strays as independent variables, differences in social interaction as moderator variables and social studies learning outcomes as dependent variables. Data collection techniques used are test techniques and non-test techniques. The test technique is used 
to filter data on social studies learning outcomes while the non test technique is a questionnaire used to filter students social interaction data of students.

The instruments used to collect research data consist of two types: (1) Student learning outcomes tests on social studies subjects aim to measure cognitive aspects in the form of multiple choices, (2) Social interaction tests. The steps for making the test are based on the opinion of Arikunto (2007: 13) which consists of (a) planning including formulation of objectives, determining the variables contained in the test grid, (b) writing item, (c) editor, namely completing the instrument with instructions and generate answer keys, (d) conduct trials, (e) analyze the results of trials, (f) make revisions. Thus the research instrument used a test of ability in the cognitive area in the form of multiple choices as many as 40 items. Each question consists of 4 answer choices that only have one correct choice.

\section{RESULT AND DISCUSSION}

\section{A. The Description of Research Data}

Based on the results of research conducted for social studies learning outcomes of students who were taught with problem based learning strategies obtained an average score of 30.76 while students who were taught with two stay two stray learning strategies only gained an average of 26.85. The social science learning outcome of students with cooperative has an average score 31.01 while the social science learning outcome of students with competitive has an average score 27.05.

\section{B. The Test of Analysis Requisite}

The test of analysis requisite data consists normality test and homogenity varians population.

1) Normality test: Normality test used liliefors with $\mathrm{H}_{0}$ that describe sample from population of normal distribution. Whether it is accepted or rejected from compared $\mathrm{L}_{\text {count }}\left(\mathrm{L}_{\mathrm{h}}\right)$ with $\mathrm{L}_{\text {tabel }}\left(\mathrm{L}_{\mathrm{t}}\right)$ at significancy $\alpha 0.05 \%$. If $\mathrm{L}_{\text {count }}<\mathrm{L}_{\text {tabel }}$, the data is normal. Normality test is used for know sample that used which one from normal population or not. There are eight groups of normality test. From test result for significancy $\alpha=$ 0.05 , the value of $\mathrm{L}_{\text {count }}$ for all groups is lower than $\mathrm{L}_{\text {tabel. }}$. So, in conclusion that data of outcome learning from all groups I,II,III,IV,V,VI,VII,VIII are normal distribution. The result of normality test can see in tabel:

TABLE 1. RECAPITULATION OF NORMALITY TEST

\begin{tabular}{|c|c|c|c|c|}
\hline $\begin{array}{c}\text { Sample } \\
\text { group }\end{array}$ & $\begin{array}{c}\text { Total } \\
\text { sample }\end{array}$ & $\mathrm{L}_{\text {count }}$ & $\mathrm{L}_{\text {tabel }}$ & Conclusion \\
\hline I & 42 & 0,051 & 0,136 & Normal \\
II & 42 & 0,036 & 0,136 & Normal \\
III & 44 & 0,087 & 0,136 & Normal \\
IV & 40 & 0,021 & 0,136 & Normal \\
V & 22 & 0,099 & 0,190 & Normal \\
VI & 20 & 0,038 & 0,191 & Normal \\
VII & 22 & 0,064 & 0,190 & Normal \\
VIII & 20 & 0,023 & 0,191 & Normal \\
& & & & \\
\hline
\end{tabular}

2) Homogenity test: Homogenity test is for know that sample varians from homogen population or not homogen population. Homogenity test is compare varians data outcome learning social study students group that taught between problem based learning with two stay two stray and between cooperative and competitive social interaction.

a) The summary of learning outcome of students in social science who are taught with problem based learning strategy and two stay two stray strategy

The result of homogenity outcome learning of social science that taught between problem based learning and two stay two stray can see in tabel II.

TABLE II. SUMMARY OF LEARNING OUTCOME OF STUDENTS IN SOCIAL SCIENCE WHO ARE TAUGHT WITH PROBLEM BASED LEARNING STRATEGY AND TWO STAY TWO STRAY STRATEGY

\begin{tabular}{|l|c|c|c|}
\hline Sample group & $\mathrm{F}_{\text {count }}$ & $\mathrm{F}_{\text {table }}$ & Explanation \\
\hline The learning & 1,27 & 1,69 & Homogen \\
outcome of & & & \\
students in & & & \\
social science & & & \\
who are taught & & & \\
with problem & & & \\
based learning & & & \\
stategy and & & & \\
two stay two & & & \\
stray strategy & & & \\
\hline
\end{tabular}

Homogenity test outcome learning social study students that taught between problem based learning with two stay two stray was value $F_{\text {count }} 1,27$, and then value $F_{\text {table }} 1.69$ in $\alpha=$ 0.05 . The value of $F_{\text {count }}$ is lower than $F_{\text {table }} 1.27<1.69$. The both of sample have the homogenous varians.

b) The summary of homogenity test social science learning outcome of students with cooperative and competitive social interaction

TABLE 3. SUMMARY OF HOMOGENITY TEST IN OUTCOME LEARNING OF STUDENTS WITH COOPERATIVE AND COMPETITIVE SOCIAL INTERACTION:

\begin{tabular}{|l|l|l|l|}
\hline \multicolumn{1}{|c|}{ Sample group } & $\mathrm{F}_{\text {count }}$ & $\mathrm{F}_{\text {tabel }}$ & Explain \\
\hline The social & 2,52 & 2,81 & Homogen \\
science learning & & & \\
outcome of & & & \\
students with & & & \\
cooperative and \\
competitive & & & \\
social & & & \\
interaction & & & \\
\hline
\end{tabular}

Homogenity test in outcome learning of students with cooperative and competitive social interaction was value $F_{\text {count }}$ 2.52 and then value $F_{\text {table }} 2.81$ in $\alpha=0.05$. The value of $F_{\text {count }}$ is lower than $F_{\text {table }} 2.52<2.81$. So, the both of sample have the homogenous varians. 
c) The summary of homogenity test in learning outcome of students in social science between learning of strategy and social interaction

TABLE 4. THE RESULT OF HOMOGENITY TEST IN LEARNING OUTCOME OF STUDENTS IN SOCIAL SCIENCE BETWEEN LEARNING OF STRATEGY AND SOCIAL INTERACTION

\begin{tabular}{|c|c|c|c|}
\hline Sample group & $\mathrm{X}_{\text {count }}^{2}$ & $X_{\text {tabel }}^{2}$ & Explain \\
\hline $\begin{array}{l}\text { Learning } \\
\text { outcome of } \\
\text { students in } \\
\text { social science } \\
\text { who are taught } \\
\text { with problem } \\
\text { based learning } \\
\text { strategy and two } \\
\text { stay two stray } \\
\text { strategy with } \\
\text { cooperative and } \\
\text { competitive } \\
\text { social } \\
\text { interaction. }\end{array}$ & 0,416 & 7,82 & Homogen \\
\hline
\end{tabular}

Test homogenity interaction between strategy and social interaction used Barlett. The value based barlet formula is $\mathrm{X}_{\text {count }}^{2} 0.416$ and $\mathrm{X}_{\text {tabel }}^{2}(\alpha=0.05)=7.82$. Based the data, the value of $X_{\text {count }}<X_{\text {tabel. }}$ So, the data is homogenous varians.

- $\quad$ Social Science Learning Outcomes of students who are taught with Problem Based Learning Strategies with Two Stay Two Stray Learning Strategies. Student learning outcomes of social studies taught with problem based learning strategies are higher than the average value of students who are taught with two stay two stray learning strategies. This indicates that the problem based learning strategy is better in increasing student's understanding of social studies than the two stay two stray learning strategy. This shows that to teach social studies subject matter is better to use problem based learning strategies than two stay two stray learning strategies.

Social sciences lessons are very interesting if taught by using problem based learning strategies so that it will make it easier for students in learning to be taught by the teacher. In this study, based on the first hypothesis testing, the application of problem based learning strategies obtained significantly different effect on student learning outcomes in social studies where $\mathrm{F}_{\text {count }}>$ $F_{\text {table }}$ so that for the first research hypothesis $H_{a}$ is accepted and $\mathrm{H}_{\mathrm{o}}$ is rejected. Therefore, the two stay two stray learning strategy is less effective to facilitate students in learning because in this learning students are only assigned to convey the results of their group discussions to other groups and there is no positive interdependence so that the knowledge they gain is not as much as that obtained by students which uses problembased learning strategies.
- Social studies learning outcomes of students who have cooperative social interactions and Social learning outcomes of students who have competitive social interactions

The second hypothesis testing shows that students who have cooperative social interactions obtain higher social studies learning outcomes than students who have competitive social interactions. According to Chaplin (in Setiawati, 2010: 57) [6] social interaction is a process of reciprocity between individuals and other individuals and they influence each other. This proves that social interaction is significant to differentiate social studies learning outcomes.

From the overall data analysis results, the average social studies learning outcomes of students with cooperative social interactions are higher than the results of social studies learning students who have competitive social interactions. This is explain that students who have cooperative social interactions more understand teaching material being learned when compared to students who have competitive social interactions.

The findings of this study support previous research which states that students who have cooperative social interactions have higher learning outcomes when compared to the learning outcomes of students who have competitive social interactions. Student learning outcomes taught by two stay two stray learning strategies that have cooperative social interactions with students taught with two stay two stray learning strategies that have competitive social interactions have insignificant differences because students who have competitive social interactions are appropriately taught using two stay two stray learning strategies are compared with students who have cooperative social interactions taught by two stay two stray learning strategies.

- Interaction between learning strategies and social interactions on students' social studies learning outcomes

The findings of this study indicate that there is an interaction between learning strategies and social interactions in influencing student's social studies learning outcomes. When seen the average social studies learning outcomes of students taught with problem based learning strategies and cooperative social interactions are higher than the average learning outcomes of social studies students taught with two stay two stray learning strategies and cooperative social interactions. Then the average social studies learning outcomes of students taught with problem based learning strategies and competitive social interactions are higher than the average learning outcomes of social studies students taught with two stay two stray learning strategies and competitive social interactions.

Submission of the third hypothesis is an interaction between learning strategies and social interactions on 
student's social studies learning outcomes. When viewed from the average social studies learning outcomes of students in groups of students who are taught with problem based learning strategies that have higher cooperative social interactions. Then the average social studies learning outcomes of students with competitive social interaction that are taught with problem based learning strategies are lower than the average learning outcomes of students with competitive social interaction who are taught with two stay two stray learning strategies.

One of the supporting studies is, Susilawati (2003) [7] concludes that groups of students who have a form of cooperative social interaction score better learning outcomes than groups of students who have competitive social interactions. Research findings indicate that there is an interaction between learning strategies and social interactions on learning outcomes. Students with cooperative social interaction are trained to be able to socialize through teamwork that is carried out during learning activities.

\section{CONCLUSION}

Based on the results of research and discussion that has been stated previously, then in this study it can be concluded that:

Social science learning outcome of students who are taught with problem based learning strategies are higher than students who are taught with two stay two stray learning strategies.

Social science learning outcome of students who have cooperative social interactions are higher than students who have competitive social interactions.

- $\quad$ There is an interaction between learning strategies and social interactions on social science learning outcome. Students who have cooperative social interactions get higher social science learning outcomes if they are taught using problem based learning strategies rather than two stay two stray learning strategies, while students who have competitive social interaction have higher learning outcomes if they are taught with two stay two stray learning strategies than problem based learning strategy.

\section{REFERENCES}

[1] Waite, J.L \& Hume, S.E. (2016). Developing Mission-Focused Outcomes for a Professional Conference: The Case of the National Conference on Geography Education. Journal of Geography, 116 (3), 127-135. doi 10.1080/00221341.2016.1243722

[2] Weiss, G. (2017). Problem-Oriented Learning in Georaphy Education: Construction of Motivating Problems. Journal of Geography, 116 (5), 206-216. doi: 10.1080/00221341.2016.127262

[3] Sapriya. 2009. Pendidikan IPS: Konsep dan Pembelajaran. Bandung: Remaja Rosdakarya
[4] Supardan, Dadang. 2015. Pembelajaran Ilmu Pengetahuan Sosial: Perspektif Filosofi dan Kurikulum. Jakarta: Bumi Aksara

[5] Rachmah, Huriah. 2014. Pengembangan Profesi Pendidikan IPS. Bandung Alfabeta

[6] Setiawati, Eka \& Suparno. 2010. Interaksi Sosial dengan Teman Sebaya pada Anak Homeschooling dan Anak Sekolah Reguler (Study Deskriptif Komparatif). Jurnal: Indigenous: Jurnal Ilmiah Berskala Psikologi.12 (01): 57

[7] Susilawati. 2005. Pengaruh Strategi Pembelajaran dan Interaksi Sosial Terhadap Hasil Belajar PPKN Siswa SMP Kota Tanjung Balai. Tesis : Medan: Program Pascasarjana UNIMED 